\title{
PERKAWINAN BEDA AGAMA PERSPEKTIF MAJELIS ULAMA INDONESIA DAN MUHAMMADIYAH
}

\author{
Miftakul Bil Ibad \\ Lembaga Pendidikan Islam Sabilillah Malang. E-mail: \\ ibadmiftah1905@gmail.com.
}

\begin{abstract}
This article discusses interfaith marriage law according to the fatwa of the Indonesian Ulema Council and Mubammadiyah. According to the MUI's fatwa, interfaith marriages are unlanful with the proposition of chapter of al-Baqarah verse 221. While Muhammadiyah believes interfaith marriages are permissible on the basis of al-Maidah verse 5. MUI forbids interfaith marriages because it can lead to conflicts between Muslims and cause unrest in the community. Muhammadiyah allows interfaith marriages because in Islamic history it is known that the Prophet Mubammad was married to a Christian woman from Egypt, namely Maria al-Qibthiyyah. Some of the Companions of the Prophet also married the women of the Book. MUI equates ablu al-Kitab (Nashrani and Jewish) including the category of polytheists, while Muhammadiyah considers that women from ablu al-Kitab does not include polytheists as stated in chapter al-Baqarah verse 221. This is because according to Mubammadiyah there are many verses that distinguish between ablu al-Kitab and polytheism by considering the linguistic analysis in chapter al-Baqarah verse 105 and al-Bayyinah verse 1.
\end{abstract}

Keywords: Interfaith marriages, Mubammadiyyah, Indonesian Ulema Council.

Abstrak: Artikel ini membahas tentang hukum perkawinan beda agama menurut fatwa Majelis Ulama Indonesia dan Muhammadiyah. Menurut fatwa MUI, perkawinan beda agama adalah haram dengan dalil surat alBaqarah ayat 221. Sedangkan Muhammadiyah beranggapan peerkawinan beda agama adalah boleh dengan dasar surat al-Maidah ayat 5. MUI mengharamkan perkawinan beda agama karena hal tersebut bisa menimbulkan konflik antar sesama umat Islam dan mengakibatkan keresahan di masyarakat. Muhammadiyah membolehkan perkawinan beda agama karena dalam sejarah Islam diketahui bahwa Nabi Muhammad Saw pernah menikah dengan seorang wanita Nasrani yang berasal dari Mesir, yaitu Maria al-Qibthiyyah. Beberapa sahabat Nabi juga menikah dengan wanita-wanita ablu al-Kitab. MUI menyamakan ablu al-Kitab (Nashrani dan Yahudi) termasuk kategori musyrik, sedangkan Muhammadiyah beranggapan bahwasanya wanita ablu al-Kitab itu tidak termasuk musyrikat sebagaimana yang tercantum dalam surat al-Baqarah ayat 221. Hal tersebut disebabkan menurut Muhammadiyah banyak ayat yang menbedakan

AL-HUKAMA

The Indonesian Journal of Islamic Family Law Volume 09, Nomor 01, Juni 2019; ISSN:2089-7480 
Miftakul Bil Ibad: Perkawinan Beda Agama......

antara ablu al-Kitab dengan musyrik dengan mempertimbangkan analisis kebahasaan dalam surat al-Baqarah ayat 105 dan al-Bayyinah ayat 1.

Keywords: Perkawinan beda agama, Muhammadiyyah, Majelis Ulama Indonesia.

\section{Pendahuluan}

Secara sosio-antropologis Indonesia merupakan sebuah negara yang terdiri dari berbagai macam suku, golongan, ras, budaya dan agama, hal tersebut dikarenakan pengaruh sebuah faktor tertentu. Faktor tersebut di antaranya adalah keadaan geografis negara Indonesia. Hal ini menjadi faktor tervital dalam terciptanya akulturasi yang begitu beragam. Selain faktor tersebut, teritorial negara Indonesia terletak di antara dua benua yaitu benua Asia dan Eropa, serta dua samudera, yaitu samudera Hindia dan samudera Pasifik. Jika dilihat dari letaknya yang diapit oleh dua benua dan samudera, tentunya sangat besar sekali potensi dalam berkembangnya pluralitas budaya, ras, dan agama dalam masyarakat Indonesia (pluralis society).1 Kebudayaan merupakan sebuah karya, cipta, dan rasa yang dibuat oleh umat manusia yang terus diwariskan secara turun-temurun dari generasi ke generasi berikutnya. Kebudayaan merupakan sebuah implementasi dari kemampuan masyarakat dalam menyikapi suatu kondisi yang ada. Kebudayaan juga sangat mempengaruhi corak dan cara berkehidupan. Kebudayaan akan terus berkembang seiring dengan berkembangnya kemampuan manusia.2

Adapun agama-agama yang mempengaruhi terciptanya pluralitas di Indonesia adalah Islam, Kristen Katholik dan Protestan, Hindu, Budha, dan Konghuchu. Kondisi tersebut memaksa negara untuk melindungi hak-hak rakyat dalam memilih agama yang sesuai dengan hati nurani dan kepercayaannya.

Hak rakyat dalam menentukan keyakinannya masing-masing tertuang dalam Undang-Undang Dasar 1945 Pasal 29 ayat (2)3 yang

1 Ratna Jati Ningsih, "Perkawinan Beda Agama (Studi Analisis Pemikiran Quraish Shihab dalam Tafsir Al-Misbah)", (Skripsi--IAIN Surakarta, 2012), 1.

2 Kamto, "Perkawinan Masyarakat Samin dalam Perpektif Sosiologis dan Teologis", Jurnal Studi Hukum Islam, Vol. 3, No. 2, (Juli-Desember, 2016),143. 3 Undang-Undang Dasar Negara Republik Indonesia 1945 Pasal 29 Ayat (2). 
menyatakan bahwa, negara menjamin kemerdekaan tiap-tiap penduduk untuk memeluk agama masing-masing dan beribadat menurut agama dan kepercayaannya.

Dengan beragamnya pluralitas dan keragaman tersebut, bukan tidak mungkin akan terjadi sebuah interaksi sosial di antara kelompok-kelompok yang beragam tersebut, baik itu berbincangbincang, jual beli, atau bahkan sampai berlanjut kepada sebuah hubungan perkawinan yang berbeda keyakinan.

Perkawinan bagi umat manusia merupakan suatu prosesi yang sangat sakral, dikarenakan tujuan utama dari berlangsungnya perkawinan adalah melestarikan keturunan umat manusia. Tanpa adanya hubungan yang jelas akan menyebabkan kekacauan di masyarakat, bahkan yang paling menyedihkan apabila hal itu tidak diatur secara tegas adalah terjadinya perkumpulan kebo atau seks bebas yang akibatnya sangat fatal.4

A. Djazuli menjelaskan bahwasanya perkawinan adalah akad yang menghalalkan pergaulan antara seorang laki-laki dan perempuan serta menetapkan hak-hak dan kewajiban di antara keduanya.5

Pernikahan atau biasa juga disebut sebagai perkawinan adalah sebuah upacara pengikatan antara dua orang antara laki-laki dan perempuan dengan sebuah janji, dengan tujuan untuk membangun sebuah keluarga yang sejahtera dan bahagia, serta membangun sebuah tanggung jawab bagi keduanya.

Di Indonesia, perkawinan diatur dalam undang-undang nomor 1 tahun 1974 tentang perkawinan, oleh karenanya perkawinan juga merupakan sebuah tindakan hukum. Di dalam undang-undang tersebut diatur bahwasanya bagi orang Indonesia diwajibkan untuk mencatatkan perkawinannya kepada pejabat yang berwenang sebagai bentuk jaminan kepastian hukum.6

Perkawinan beda agama sudah ada sejak zaman Rasulullah Saw sampai sekarang. Karena kecanggihan ilmu pengetahuan dan

4 Dede Rihana, "Pernikahan Beda Agama Prespektif Al-Qur'an (Kajian SosioHistoris Terhadap QS. Al-Mumtahanah/60: 10)", (Skripsi--UIN Syarif Hidayatullah, Jakarta, 2017), 3.

5 A. Djazuli, Imu Fiqh, (Jakarta: Prenada Media Group, 2010), 48.

6 Undang-Undang No. 1 Tahun 1974 tentang Perkawinan. 
teknologi di masyarakat sekarang, tidak menutup kemungkinan seseorang melakukan perkawinan dengan orang lain yang memiliki perbedaan kepercayaan atas dasar cinta semata.

Praktik perkawinan yang semakin banyak di kalangan masyarakat tentunya menjadi sebuah polemik dalam kehidupan. Disadari maupun tidak, hal tersebut merupakan salah satu problem sosial kemasyarakatan yang telah menjadi sebuah realita yang semakin meninggi. Fenomena tersebut disatu sisi merupakan bagian dari permasalahan yang menuntut solusi hukum Islam. Di sisi lain juga merupakan problem krusial yang senantiasa mengharapkan sekaligus menuntut jawaban arif dan bijaksana dari para ulama.7

Berdasarkan realita yang ada, perkawinan beda agama menimbulkan penafsiran-penafsiran hukum berbeda antara golongan satu dengan yang lainnya. Organisasi masyarakat (Ormas) yang ada di Indonesia berbeda pendapat dalam menghukumi perkawinan beda agama ini, ada yang membolehkan, ada juga yang membolehkan dengan syarat, bahkan ada juga yang secara tegas mengharamkan perkawinan beda agama.

Ormas yang membolehkan terjadinya perkawinan beda agama adalah ormas Muhammadiyah. Perkawinan beda agama dibolehkan dikarenakan ormas Muhammadiyah meyakini bahwa surat alMaidah ayat 5 merupakan kekhususan dari keumuman surat alBaqarah ayat 221. Sedangkan organisasi yang mengharamkan tejadinya perkawinan beda agama adalah Majelis Ulama Indonesia (MUI). MUI menghukumi perkawinan beda agama merupakan sebuah perilaku yang diharamkan dikarenakan banyaknya kemadharatan atau mafsadah yang ditimbulkan oleh perkawinan ini.Hal tersebut tertuang pada fatwa MUI Nomor: 4/MUNAS VII/MUI/8/2005 tentang Perkawinan Beda Agama. Fatwa tersebut menjelaskan bahwasanya perkawinan beda agama ini hukumnya haram dan tidak sah. Demikian laki-laki Muslim dengan wanita ahli kitab menurut qaul mu'tamad adalah hukumnya haram dan tidak sah.

Berdasarkan latar belakang di atas, penulis tertarik untuk membahas hukum perkawinan beda agama perspektif Majelis Ulama Indonesia dan Muhammadiyah.

7 Desri Ari Enghariano dan Amaruddin Asra, "Pernikahan Beda Agama Menurut Rasyid Ridha dan Al-Maraghi”, Jurnal Syahadah, Vol. V, No. 1, (April, 2017), 72. 


\section{Perkawinan dalam Hukum Islam}

Perkawinan adalah sebuah ikatan lahir batin antara seorang laki-laki dengan seorang perempuan dengan maksud tujuan membina keluarga yang sejahtera dan bahagia, baik di dunia maupun di akhirat kelak.8 Dengan ikatan lahir bathin tersebut, perkawinan tidak semata-mata hanya terkait sesuatu yang tampak di lihat oleh mata saja. Melainkan ikatan perkawinan ini dituntut untuk memenuhi juga apa yang tidak terlihat. Jika dari kedua hal tersebut termenuhi, maka akan terbentuklah keluarga yang sakinah, mawaddah, dan warahmah.

Dalam tradisi masyarakat Indonesia, perkawinan bisa dinilai sebagai sebuah ritual yang dilakukansecara khidmat dan sakral karena harus mematuhi sebuah aturan dan syarat-syarat tertentu dalam menjalankannya. Tindakan tersebut didasari kepada keyakinan religius terhadap kekuasaan atau kekuatan-kekuatan mistis.9

Dalam sudut pandang sosiologi perkawinan merupakan upaya membentuk dan melanjutkan tradisi yang ada dalam suatu masyarakat tertentu.10Dengan demikian bisa disimpulkan bahwasanya tujuan dari sebuah perkawinan adalah melanjutkan tradisi ke keturunannya. Tanpa adanya keturunan yang melanjutkan, sulit rasanya tradisi bisa dikenal oleh kalangan masyarakat luar. Bahkan banyak sekali tradisi yang hilang karena kurang sadarnya masyarakat mempertahankan tradisi yang dimiliki.

Perkawinan dalam Undang-Undang Nomor. 1 tahun 1974 tentang Perkawinan terdapat pada Pasal 1, yaitu ikatan lahir bathin antara seorang pria dengan seoaran wanita sebagai suami istri degan tujuan mmbentuk keluarga (rumah tangga) yang bahagia dan kekal

8 Yedi Purwanto, "Kawin Beda Agama dan Perlindungan Ham : Studi Kritis atas Undang-Undang Pernikahan Nomor 1 Tahun 1974 dan Undang-Undang Dasar 1945”, Jurnal, Asy-Syariab, Vol. 16, No. 3, (Desember, 2014), 216.

9 Muhammad Taufiq dan Anis Tyas Kuncoro, "Pasuwitan Sebagai Legalitas Perkawinan: Telaah Hukum Islam terhadap Perkawinan Suku Samin di Kabupaten Pati”, Jurnal Ulul Albab, Vol. 1, No. 2, (April, 2018), 56.

10 Kamto, "Perkawinan Masyarakat Samin dalam Perpektif Sosiologis dan Teologis",Isti'dal, Jurnal Studi bukum Islam, Vol. 3, No. 2, (Juli-Desember, 2016), 147. 
berdasarkan ketuhanan yang maha esa.11Dari pengertian tersebut dapat disimpulkan bahwa tujuan utama perkawinan adalah menciptakan kehidupan keluarga yang harmonis.Dengan keadaan yang harmonis tersebut pernikahan menjadi kekal dan bahagia bagi para pelakunya.

Perkawinan menurut Imam Syafi'i adalah sebuah akad yang menghalalkan hubungan badan (seksual) antara laki-laki dan perempuan.12Sedangkan Imam Hanafi mengaartikan perkawinan sebagai sebuah akad yang memberikan kepemilikan untuk bersenang-senang secara sengaja.Artinya akad tersebut menjadikan seoarng laki-laki boleh menikmati perempuan yang ia nikahi secara syari'at dengan sebuah kesengajaan.13

Dari beberapa pengertian di atas dapat disimpulkan bahwasanya perkawinan adalah sebuah prosesi (akad) yang dilakukan oleh laki-laki dan perempuan untuk memperoleh kehalalan berhubungan badan dengan tujuan menapatkan kehidupan yang bahagia dan sejahtera di dunia dan akhirat dengan memenuhi hak dan kewajiban masing-masing.

Perkawinan adalah sebuah akad yang menjadikan halal pergaulan antara seorang laki-laki dan perempuan serta menetapkan hak dan kewajiban bagi keduanya.14 Dalam al-Qur'an yang menjadi dasar perkawinan adalah surat an-Nisa' ayat 3, yaitu:

Dan jika kamu tidak akan berlaku adil terbadap anak yatim, maka kawinilah perempuan-perempuan lain yang kamu senangi, dua, tiga, atau empat dan jika kamu takut tidak akan berlaku adil, cukup satu orang.(Q.S. an-Nisa':3)

Selain ayat di atas, dasar perkawinan juga terdapat dalam surat al-A'raaf ayat 189 , yaitu:

Dialah yang menciptakan kamu dari diri yang satu dan dari padanya Dia menciptakan isterinya, agar dia merasa senang kepadanya. (Q.S. al-A'raaf: 189)

11 Subekti, Kitab Undang-Undang Hukum Perdata, UUPA dan UU Perkawinan, (Jakarta: Pradniya Paramita, 2004), 537.

12 Idris Ramulyo, Hukum Perkawinan Islam, (Jakarta: Bumi Aksara, 1999), 2.

13 Wahbah az-Zuhaili, Figh Islam Wa Adillatubu, (Jakarta: Gema Insani, 2011), 39.

14 A. Djazuli, Ilmu Fiqh, (Jakarta: Prenada Media Group, 2010), 48. 
Ulama berbeda pendapat dalam hukum melakukan perkawinan ada yang membolehkan, ada yang sunnah dan ada pula yang wajib, bahkan ada pula yang mengharamkan. Dalam buku Figh Munakahat karya Abdul Rahman Ghozali, Ibnu Rusyd menjelaskan bahwasanya hukum melakukan perkawinan menurut ulama jumhur (mayoritas ulama) adalah sunnah. Golongan Dhohiriyyah menghukumi perkawinan itu wajib.Sedangkan mazhab Malikiyyah mutaakhirrinmenghukumi perkawinan itu bisa saja wajib, Sunnah, dan mubah bagi seseorang sesuai dengan kekhawatiran (kesusahan) orang tersebut. 15

Adapun hukum asal dari perkawinan itu adalah mubah, akantetapi bisa berubah menurut ahkamul khomsah sesuai dengan perubahan situasi dan kondisi yang ada.16 Hal ini dapat dijabarkan sebagai berikut:

1. Wajib: Bagi orang yang memiliki kemampuan dan kemauan untuk melaksanakan perkawinan dan dikhawatirkan akan berbuat zina apabila tidak melaksanakan perkawinan.

2. Sunnah: Bagi orang yang memiliki kemampuan dan kemauan untuk melaksanakan perkawinan akantetapi tidak dikhawatirkan akan berbuat zina apabila tidak melaksanakan perkawinan.

3. Haram: Bagi orang yang tidak memiliki kemampuan dan kemauan serta tanggungjawab untuk melaksanakan kewajiban dalam perkawinan.

4. Makruh: Bagi orang yang memiliki kemampuan dan juga cukup mempunyai kemampuan untuk menahan diri dari perbuatan zina sekiranya ia tidak melakukan perkawinan, akantetapi orang tersebut tidak mempunyai keinginan yang kuat dalam memenuhi kewajiban dari perkawinan.

5. Mubah: Bagi orang yang memiliki kemampuan dan juga cukup mempunyai kemampuan untuk menahan diri dari perbuatan zina sekiranya ia tidak melakukan perkawinan dan apabila melakukannya tidak akan menelantarkan apa yang menjadi tanggungjawabnya.

15 Abdul Rahman Ghozali, Figh Munakahat, (Jakarta: Kencana, 2010), 16. 16 M. A. Tihani, Fikih Munakahat, (Jakarta: Rajawai Pers, 2010), 10. 
Dari uraian di atas dapat menjelaskan bahwasanya hukum melakanakan perkawinan dalam Islam adalah bisa wajib, sunnah, haram, makruh, dan mubah, hal tersebut sesuai dengan keadaan maslahat dan mafsadatnya.

Rukun dan syarat merupakan dua hal yang tidak bisa dipisahkan dalam suatu perbuatan hukum.Hal ini dikarenakan dua kata tersebut merupakan sebuah unsur yang harus ada dalam suatu perbuatan hukum, terlebih lagi bila dikaitkan dengan sah atau tidaknya hukum suatu perbatan tersebut.Sebagai sebuah perbuatan hukum perkawinan juga memiliki syarat dan rukun sendiri.Perkawinan tidak sah bila keduanya tidak terpenuhi.

Pengertian rukun perkawinan adalah sesuatu yang berada dalam hakikat dan merupakan sebuah unsur yang mewujudkan sah atau tiaknya perkawinan.Contoh rukun adalah kedua mempelai dalam perkawinan.17 Bila tidak ada kedua mempelai, tentunya perkawinan itu tidak akan bisa terjadi. Sedangkan yang dimaksud syarat perkawinan adalah faktor-faktor yang harus dipenuhi oleh para pelaku hukum yang merupakan bagian dari akad perkawinan.18Contoh syarat adalah mempelai harus beragama Islam.

1. Rukun perkawinan

Dalam Kompilasi Hukum Islam19 rukun nikah terdapat dalam Pasal 14, yaitu sebagai berikut:

a. Adanya calon suami dan istri yang tidak terhalang dan terlarang secara syar'i untuk menikah.

b. Adanya ijab, yaitu lafadz yang diucapkan oleh wali atau yang menggantikan posisi wali.

c. Adanya qabul, yaitu lafadr yang diucapkan oleh suami atau yang mewakilinya.

d. Wali adalah pengasuh pengantin perempuan pada waktu menikah atau orang yang melakukan janji nikah dengan pengantin laki-laki.

17Amir Syarifuddin, Hukum Perkawinan di Indonesia: Antara Fiqih Munakahat dan Undang-Undang Perkawinan, (Jakarta: Kencana, 2009), 59.

18 Neng Djubaidah, Pencatatan Perkawinan dan Perkawinan Tidak dicatat, Jakarta: Sinar Grafika, 2010), 107.

19Pasal 14 Kompilasi Hukum Islam. 
e. Dua orang saksi, adalah orang yang menyaksikan sah atau tidaknya suatu pernikahan. Hal ini sesuai dengan hadits nabi Muhammad Saw yang diriwayatkan oleh imam Ahmadyaitu sebagai berikut:

Tidak ada nikah kecuali dengan adanya wali dan dua saksi yang adil.

Syarat perkawinan merupakan sebuah dasar bagi sahnya hukum suatu perkawinan. Tanpa terpenuhinya syarat perkawinan, tentunya apa yang dilakukan menjadi sia-sia. Sebaliknya apabila syarat tersebut terpenuhi maka perkawinan tersebut menjadi sah dan mengakibatkan tanggungjawab bagi para pelaku sebuah perkawinan. 20

Secara garis besarnya sebuah perkawinan dapat dianggap sah bila memenuhi dua syarat, yaitu sebagai berikut:21

1. Calon mempelai perempuan halal untuk dinikahi seorang mempelai laki-laki.

2. Pada saat akad nikah dihadiri para saksi.

Secara rinci syarat di atas akan dijelaskan sebagai berikut:

a. Syarat mempelai laki-laki

Seorang mempelai laki-laki yang akan melangsungkan perkawinan harus memenuhi beberapa syarat yang telah diatur syari'at Islam, yaitu:

1) Beragama Islam

2) Benar-benar seorang laki-laki

3) Orangnya diketahui dan tertentu

4) Halalnya seorang mempelai laki-laki kawin dengan calon istrinya.

5) Calon mempelai laki-laki kenal serta tau bahwa halal menikahi calon istrinya

6) Calon mempelai laki-laki rela (tidak terpaksa) dalam melangsungkan perkawinan

7) Tidak sedang ihram

b. Syarat mempelai perempuan

20Abdul Rahman Ghozali, Fiqh Munakahat, 49.

21Ibid 
Syarat seorang perempuan yang akan melangsungkan perkawinan adalah sebagai berikut:

1) Islam atau ahli kitab

2) Benar-benar seorang perempuan

3) Halal bagi calon suaminya

4) Tidak dalam ikatan perkawinan dan tidak sedang masa iddah

5) Tidak dipaksa

6) Tidak daam keadaan ihram

c. Syarat wali

Syarat seorang yang bisa menjadi wali perkawinan adalah sebagai berikut:

1) Laki-laki

2) Islam

3) Baligh

4) Berakal

5) Adil

6) Tidak ihram

d. Syarat saksi

Syarat seorang bisa menjadi saksi sebuah perkawinan adalah sebagai berikut:

1) Laki-laki

2) Islam

3) Baligh

4) Berakal

5) Melihat dan mendengar serta mengerti apa yang dimaksud akad nikah

\section{Tujuan dan Hikmah Perkawinan}

Perkawinan merupakan sebuah acara yang sangat suci bagi semua orang. Hal ini dengan adanya suatu perkawinan yang sah akan muncul pula sebuah generasi penerus umat manusia dalam melanjutkan kehidupan yang diberikan oleh Allah Swt.

Tujuan utama dilangsungkannya perkawinan adalah untuk menciptakan keluarga yang sakinah, mawaddah, warahmah.Hal tersebut menjadikan keluarga yang selalu menjaga keharmonisan dan kebahagian dalam mengarungi kehidupan berumah tangga serta 
selalu menjunjung tinggi kesejahteraan hidup.22 Hal ini sesuai dengan apa yang ada dalam Kompilasi Hukum Islam Pasal 3 yaitu tujuan dari dilangsungkannya sebuah perkawinan adalah untuk mewujudkan kehidupan rumah tangga yang sakinah, mawadah, dan rahmah.23

Adapun tujuan sebuah perkawinan dalam Undang-Undang Nomor 1 Tahun 1974 tentang Perkawinan adalah sebagaipembentuk keluarga atau rumah tangga yang bahagia dan kekal berdasarkan Ketuhanan Yang Maha Esa.24Banyak sekali faktor yang harus diperhatikan guna terwujudnya keluraga yang bahagia serta kekal sampai kematian menjemput.Faktor tersebut antara lain adalah kesiapan dankematangan calon suami maupun istri untuk berumah tangga. Kesiapan dan kemantangan inimencakup fisik, mental, dan material.Dengan kesiapan serta kematangan yang dimiliki kedua calon tersebut tentunya persoalan yang begitu rumitpun dapat dihadapi dengan tidak terjadinya sebuah perceraian. 25

Dalam buku Hukum Perkawinan Islam dan Undang-Undang Perkawinan karya Soemiyati26, Imam Ghozali menyebutkan tujuan perkawinan dibagi menjadi lima yaitu:

1. Memperoleh keturunan yang sah yang akan melangsungkan generasi selanjutya.

2. Memenuhi tuntutan naluriah kehidupan manusia.

3. Memelihara manusia dari kejahatan dan kerusakan.

4. Membentuk dan mengatur rumah tangga atas dasar cinta dan kasih sayang.

5. Menumbuhkan usaha untuk mencari rezeki secara halal serta menumbuhkan rasa tanggunjawab.

22 Wasman dan Wadah Nuroniyah, Hukum Perkawinan Islam di Indonesia, (Yogyakarta: Teras, 2011), 37.

23 Pasal 3 Kompilasi Hukum Islam

24 Pasal 1 Undang-Undang Nomor 1 Tahun 1974 tentang Perkawinan

25Sofia Hardani, "Analisis tentang Batas Umur Untuk Melangsungkan Perkawinan menurut Perundang-Undangan di Indonesia", An-Nida': Jurnal Pemikiran Islam, Vol. 40, No. 2, (Juli-Agustus, 2015), 130.

26Soemiyati, Hukum Perkawinan Islam dan Undang-Undang Perkawinan, (Yogyakarta: Liberty, 2007), 12. 
Allah Swt mensyari'atkan sebuah perkawinan tentunya memiliki nilai yang begitu besar manfaatnya dalam kehidupan manusia.Untuk mencapai kehidupan yang bahagia, Allah Swt telah membekali syariat dan hukum Islam agar manusia dapat melaksanakannya. Hikmah dari adanya sebuah perkawinan adalah sebagai berikut:

1. Memelihara gen manusia. Perkawinan merupakan sebuah sarana untuk memelihara keberlangsunga gen manusia. Dengan adanya sebuah prosesi perkawinan yang sesuai dengan apa yang ada dalam syari'at, kehidupan manusia akan menjadi makmur serta dapat menjalankan tugas sebagai khalifah di dunia yang diberikan Allah Swt.

2. Perkawinan merupakan tiang keluarga yang teguh dan kokoh. Hal ini dikarenakan dalam sebuah perkawinan ada sebuah ikatan yang begitu sakral dan religius. Seseorang akan merasakan adanya sebuah sensasi yang mengikat secara suci yang membuat tinggi derajat kemanusiaannya.

3. Perkawinan sebagai sebuah perisai dalam diri manusia. Sebuah perkawinan akan mengarahkan manusia untuk menjauhi pelanggaran-pelanggaran yang haram dalam agama. Karena dalam ikatan perkawinan memperbolehkan masing-masing pihak (suami-istri) untuk melaksanakan hajat biologisnya secara halal dan mubah.27

Selain hal-hal yang tersebut di atas, hikmah dari sebuah perkawinan dalam buku Fiqh Munakahat karya Abdul Rahman Ghozali28, menurut Sayyid Sabiq adalah sebagai penyalur maluri seks, jalan untuk memperoleh keturunan yang sah, menjadikan seseorang memiliki sifat kebapakan dan keibuan, sebuah dorangan untuk berusaha lebih keras lagi, dan menjalin silaturahmi bagi kelurga pasangan suami istri.

\section{Profil Majelis Ulama Indonesia}

Majelis Ulama Indonesia atau yang biasa disingkat dengan MUImerupakan sebuah lembaga kemasyarakatan yang dibentuk untuk menghimpun para ulama, zuama' dan cendekiawan muslim

27 Abdul Majid Khon, Fiqh Munakahat, (Jakarta: Amzah, 2011), 39. 28Abdul Rahman Ghozali, Fiqh Munakahat, 72. 
Indonesia yang mana mereka memiliki tugas untuk membimbing, membina, dan mengayomi umat Islam di seluruh wilayah Indonesia. Selain hal tersebut MUI juga memiliki tugas untuk menyatukan gerak dan langkah-langkah umat Islam Indonesia agar tercapainya suatu cita-cita bersama.29

MUI merupakan sebuah lembaga non-pemerintah yang menaungi keseluruhan umat Islam yang ada di Indonesia tanpa pernah memandang kecenderungan paham keagamaan dan organisasi kemasyarakatannya.30Majelis Ulama Indonesia berdiri pada tanggal 17 Rajab 1395 H di Jakarta. Bertepatan dengan tanggal 26 Juli 1975 M. Yang mana berdirinya MUI tersebut bertepatan pada hasil musyawarah para ulama, zuama', dan cendekiawan muslim yang datang dari berbagai penjuru tanah air. Peserta yang datang dalam pertemuan dan musyawarah ulama tersebut terdiri dari 26 orang ulama mewakili 26 Provinsi di Indonesia, 10 orang ulama dari ormas-ormas Islam tingkat pusat (NU, Muhammadiyah, Syarikat Islam, Persatuan Islam, al-Wasliyah, Mathla'ul Anwar, Gabungan Usaha-usaha Pengembangan Pendidikan Islam, Pusat Tinggi Dakwah Islam, Dewan Masjid Indonesia, dan al-Ittihadiyah), 4 orang ulama dari Dinas Rohani Islam (AD, AU, AL DAN POLRI), serta 13 tokoh cendekiawan yang merupakan tokoh perorangan.31

Hasil musyawarah yang diikuti oleh para wakil-wakil ormas tersebut, melahirkan sebuah kesepakatan untuk membentuk wadah sebagai tempat untuk bermusyawarah para ulama yang tertuang dalam sebuah "PIAGAM BERDIRINYA MUI".Kemudian hasil dari musyawarah tersebut ditandatangani oleh seluruh peserta

29Ernawati, "Studi Komparatif Metode Istinbat Nahdlatul Ulama dan Majelis Ulama Indonesia tentang Hukum BPJS Kesehatan", (Skripsi-UIN Walisongo, Semarang, 2018), 40.

30Iffatul Umniati Ismail, "Telaah Kritis Metodologi Istinbath MUI (Studi Kasus Fatwa tentang Golput)", Jurnal Media Syariah, Vol. XIII No. 1, (Januari - Juni, 2011), 74.

31Nasrullah, "Majelis Ulama Indonesia (MUI); Studi atas Penggunaan Metodologi Qiyas sebagai Upaya Penetapan Hukum Islam di Indonesia", Al-Fikra: Jurnal Ilmiah Keislaman, Vol. 16, No. 2, (Juli - Desember, 2017), 340. 
musyawarah yang diberi nama dengan sebutan munas (Musyawarah Nasional) yang pertama MUI.32

Adapun alasan yang melatar belakangi berdirinya Majelis Ulama Indonesia adalah sebagai berikut:33

a. Telah terbentuknya Majelis Ulama dari berbagai negara yang menjadi penasehat tertinggi dalam bidang keagamaan dan memiliki peran strategis.

b. Untuk mewakili umat Islam Indonesia jika terdapat pertemuanpertemuan ulama Internasional.

c. Untuk membantu pemerintah dalam memberikan pertimbanganpertimbangan keagamaan dalam upaya pelaksanaan pembangunan, contohnya yaitu sebagai jembatan penghubung dan penterjemah komunikasi antara umara dan umat Islam.

d. Sebagai wadah pertemuan dan silaturahim seluruh ulama Indonesia dalam rangka mewujudkan ukhuwah Islamiyah.

e. Sebagai wadah musyawarah bagi para ulama, zuama', dan cendekiawan muslim Indonesia dalam hal penyelesaian permasalahan umat.

Sebagai sebuah organisasi keagamaan, tentunya MUI memiliki sebuah tujuan yang harus dilaksanakan dengan sebenarbenarnya.Adapun tujuan MUI adalah sebagaimanayang tertera dalam pedoman dasar MUI yang telah mendapatkan pengesahandalam musyawarah nasional (MUNAS) pertamanya, tepatnya pada tanggal 26 Juli1975.Di mana pada Pasal 3 disebutkan bahwa MUI memiliki tujuan dalammewujudkan masyarakat yang aman berdasarkan pancasila, UUD 1945 sertaGBHN. Kemudian dalam MUNAS II, pasal 3 pedoman dasar MUIdisempurnakan menjadi: "MUI bertujuan ikut serta mewujudkan masyarakat yangaman, damai, adil, dan makmur baik dari segi jasmani maupun

32Indra Nurfiati, "Kedudukan Majelis Ulama Indonesia (MUI) dalam Ketatanegaraan Indonesia Ditinjau dari Perspektif Fiqh Siyasah”, (Skripsi-UIN Sunan Ampel, Surabaya, 2016), 61.

33Ibid, 62. 
rohani yangselalu diridhai oleh Allah SWTdalam Republik Indonesia yang berdasarkan pada pancasila. 34

Selain memiliki tujuan yang nyata, MUI dalam mewujudkan tujuan tersebut harus melaksanakan tugas dan fungsinya. Adapun yang menjadi tugas dan fungsi dari Majelis Ulama Indonesia adalah sebagaimana yang tertuang dalam MUNAS I yang terdapat pada pasal 4, yaitu sebagai berikut:35

1. Memberi fatwa dan nasehat mengenai masalah keagamaan dan masyarakat pada umumnya serta meningkatkan ketahanan nasional.

2. Memperkuat ukhuwah Islamiyah dan mewujudkan kerukunan antara umat beragama demi terwujudnya persatuan dan kesatuan nasional.

3. Mewakili umat Islam dalam berkonsultasi antar umat beragama

4. Sebagai penghubung ulama dan uamara (pemerintah) serta sebagai penerjemah timbal balik antara pemerintah dengan umat agar bisa tercapainya kesuksesan pembangunan nasional

5. Majelis ulama tidak berpolitik dan tidak operasional.

Selain fungsi di atas, Majelis Ulama Indonesia (MUI) juga memiliki lima fungsi dan peran utama yang dapat dirumuskan sebagai berikut:36

1. Sebagai pewaris tugas-tugas para Nabi (Warathatul Anbiya)

Majelis Ulama Indonesia berperan sebagai ahli waris tugastugas para Nabi, yaitu menyebarkan ajaran Islam serta memperjuangkan terwujudnya suatu kehidupan sehari-hari secara arif dan bijaksana berdasarkan Islam. Sebagai ahli waris tugas-tugas para Nabi, Majelis Ulama Indonesia menjalankan fungsi kenabian yakni memperjuangkan perubahan kehidupan agar berjalan sesuai ajaran Islam, walaupun dengan konsekuensi akan menerima kritik, tekanan, dan ancaman karena

34Heri Fadli Wahyudi dan Fajar, "Metode Ijtihad Komisi Fatwa Majelis Ulama Indonesia dan Aplikasinya dalam Fatwa", Cakrawala: Jurnal Studi Islam, Vol. 13, No. 2 (2018), 126.

35 Helmi Karim, KonsepIjtihad Majelis Ulama Indonesia dalam Pengembangan Hukum Islam, (Pekanbaru: Susqan Press, 1994), 1.

36Ernawati, "Studi Komparatif Metode Istinbat Nahdlatul Ulama dan Majelis Ulama Indonesia tentang Hukum BPJS Kesehatan”, ,......., 41. 
perjuangannya bertentangan dengan sebagian tradisi, budaya, dan peradaban manusia.

2. Sebagai pemberi fatwa (Mufti)

Majelis Ulama Indonesia berperan sebagai pemberi fatwa bagi umat Islam baik diminta maupun tidak diminta.Sebagai lembaga pemberi fatwa Majelis Ulama Indonesia mengakomodasi dan menyalurkan aspirasi umat Islam Indonesia yang sangat beragam aliran paham dan pemikiran serta organisasi keagamaannya.

3. Sebagai pembimbing dan pelayan umat (Riwayat wa khadim alummah)

Majelis Ulama Indonesia berperan sebagai pelayan umat, yaitu melayani umat dan bangsa dalam memenuhi harapan, aspirasi dan tuntutan mereka. Dalam kaitan ini, Majelis Ulama Indonesia senantiasa berikhtiar memenuhi permintaan umat, baik langsung maupun tidak langsung, akan bimbingan dan fatwa keagamaan. Begitu pula, Majelis Ulama Indonesia berusaha selalu tampil didepan dalam membela dan memperjuangkan aspirasi umat dan bangsa dalam hubungannya dengan pemerintah.

4. Sebagai gerakan Islab wa al-Tajdid

Majelis Ulama Indonesia berperan sebagai juru damai tentang perbedaan yang terjadi di kalangan umat. Apabila terjadi perbedaan pendapat di kalangan umat Islam maka Majelis Ulama Indonesia dapat menempuh jalan aljam'u wa al-taufiq (kompromi dan persesuaian) dan tarjih (mencari hukum yang lebih kuat). Dengan demikian diharapkan tetap terpelihara semangat persaudaraan (ukhuwah) dikalangan umat Islam Indonesia dan berperan sebagai pelopor tajdid yaitu gerakan pembaruan pemikiranIslam.

5. Sebagai penegak amar ma'ruf dan nabi munkar

Majelis Ulama Indonesia berperan sebagai wahana penegakan amar ma'ruf nabi munkar, yaitu dengan menegaskan kebenaran sebagai kebenaran dan kebatilan sebagai kebatilan dengan penuh hikmah dan istiqamah.Dengan demikian, Majelis Ulama Indonesia juga merupakan wadah berhidmatan bagi pejuang dakwah yang senantiasa berusaha merubah dan memperbaiki keadaan masyarakat dan bangsa dari kondisi yang tidak sejalan 
dengan ajaran Islam menjadi masyarakat dan bangsa yang berkualitas.

\section{Metode Istimbath Majelis Ulama Indonesia}

Dalam menetapkan fatwa yang berkaitan dengan permasalahan-permasalahan yang ada, MUI harus meperhatikan sumber-sumber hukum yaitu al-Qur'an, hadith, ijma', dan qiyas.Selain sumber-sumber tersebut MUI juga harus memperhatikan pendapat-pendapat para imam mazhab dan ahli fiqh terdahulu dengan mengkaji dalil-dalil tentang permaalahan yang dihadapi tersebut.

Metode yang digunakan MUI dalam upaya menetapkan sebuah fatwa adalah dengan menggunakan tiga pendekatan. Adapun tiga pendekatan tersebut dapat diuraikan sebagai berikut:37

1. Pendekatan Nash Qath'i

Pendekatan Nash Qath'I merupakan sebuah pendekatan dalam upaya menetapkan fatwa dengan langsung melihat dari alQur'an dan Hadith yang permasalahannya telah jelas ada di dalamnya.Jika dalam al-Qur'an maupun Hadith tidak ditemukan pendapat hukumnya, maka dilanjutkan dengan menggunakan pendekatan Qauli atau Manbaji.

2. Pendekatan Qauli

Pendekatan Qauli merupakan sebuah pendekatan dalam upaya menetapkan fatwa dengan mempertimbangan pendapat imam mazhab yang terdapat pada kitab-kitab fiqihterkemuka (alkutub al-mu'tabarah).Jika dalam pandangan imam mazhab dirasa tidak sesuai dikarenakan sangat sulit sekali untuk dijalankan karena adanya perubahan illat maka perlu dilakukan sebuah pengkajian ulang terkait hukum sesuatu tersebut.

3. Pendekatan Manhaji

Pendekatan Manhaji merupakan sebuah cara menyelesaikan persoalan hukum dengan jalan pikiran serta kaidah-kiadah hukum yang diciptakan oleh para imam madzhab. Pendekatan ini dirasa perlu dikarenakan dalam kandungan ajaran al-Qur'an dan al-Sunnah harus dipahami juga ditafsiri dengan

37 Heri Fadli Wahyudi dan Fajar, "Metode Ijtihad Komisi Fatwa Majelis Ulama Indonesia dan Aplikasinya dalam Fatwa",.........., 127. 
pola pemahaman serta metode yang dapat dipertanggung jawabkan kebenarannya.

\section{Pendapat Majelis Ulama Indonesia tentang Perkawinan Beda Agama}

MUI mengeluarkan fatwa tentang perkawinan beda agama, tepatnya pada tanggal 1 Juni 1980 yang kemudian sebagai penguat dari fatwa tersebut pada tanggal 28 Juli tahun 2005 fatwa tersebut oleh MUI dikeluarkan kembali dengan kata lain MUI telah mengeluarkan dua fatwa dalam satu permasalahan yang isinya adalah sama. Adapun isi dari fatwa MUI tersebut berisi:

1. Perkawinan beda agama adalah haram dan tidak sah.

2. Perkawinan laki-laki muslim dengan wanita ahlul kitab, menurut qaul mu'tamad, adalah haram dan tidak sah.38

Dalam menetapkan keharaman hukum perkawinan beda agama, MUI mengambil dasar hukum dari surat al-Baqarah ayat 221 yang berbunyi sebagai berikut:

Dan janganlah kamu menikahi wanita-wanita musyrik, sebelum mereka beriman.Sesunggubnya wanita budak yang mukmin lebih baik dari wanita musyrik, walaupun dia menarik hatimu.Dan janganlah kamu menikabkan orang-orang musyrik (dengan wanitawanita mukmin) sebelum mereka beriman.Sesunggubnya budak yang mukmin lebib baik dari orang musyrik, walaupun dia menarik hatimu.Mereka mengajak ke neraka, sedang Allah mengajak ke surga dan ampunan dengan izin-Nya.Dan Allah menerangkan ayat-ayat-Nya (perintah-perintah-Nya) kepada manusia supaya mereka mengambil pelajaran. (QS. al-Baqarah [2]: 221)

Dari ayat di atas dapat dijelaskan bahwasanya MUI beranggapan seorang laki-laki yang beragama Islam tidak boleh menikahi wanita musyrikah.MUI beranggapan bahwasanya antara wanita musyrikah dengan ablu al-Kitab itu sama-sama menyekutukan Allah Swt. Jadi menikahi keduanya hukumnya juga haram.

Selain ayat di atas juga terdapat ayat lain yang secara tegas melarang perkawinan antara seorang laki-laki muslim dengan wanita ablu al-Kitab, yaitu pada surat al-Mumtahanah ayat 10 yang berbunyi:

38 Ma'ruf Amin DKK, Himpunan Fatwa Majelis Ulama Indonesia, Jakarta: Erlangga, 2011), 477. 
Hai orang-orang yang beriman, apabila datang berbijrab kepadamu perempuan-perempuan yang beriman, maka hendaklab kamu uji (keimanan) mereka.Alllah lebih mengetabui tentang keimanan mereka; maka jika kamu telah mengetahui babwa mereka (benarbenar) beriman maka jangalah kamu kembalikan mereka kepada (suami-suami mereka) orang-orang kafir.Mereka tiada halal bagi orang-orang kafir itu dan orang-orangkafir itu tiada halal pula bagi mereka. Dan berikanlah kepada(suami-suami) mereka mahar yang telah mereka bayar. Dan tiada dosa atasmu mengawini mereka apabila kamu bayar kepada mereka maharnya. Dan janganlah kamu tetap berpegang pada tali (perkawinan) dengan perempuanperempuan kafir; dan hendaklab kamu minta mahar yang telah kamu bayar; dan hendaklah mereka meminta mahar yang telab mereka bayar. Demikianlah bukum Allah yang ditetapkan-Nya diantara kamu.Dan Allah maha mengetabui dan maha bijaksana (QS. al-Mumtahianah [60] : 10)

Dari ayat di atas dapat dijelaskan bahwasanya haram menikah dengan orang kafir.Bahkan bagi laki-laki yang telah menikah dengan wanita kafir harus segera memutuskan tali ikatannya dengan meminta kembali mahar yang telah diberikannya.

Selain hal tersebut MUI juga memakai dasar hukum hadith nabi Muhammad Saw yang diriwayatkan Abu Hurairah $r>$.a sebagai berikut:

Wanita itu boleh dinikahi karena empat hal: 1) karena hartanya 2) karena keturunannya 3) karena kecantikannya 4) karena agamanya. Maka hendaklah kamu berpegang teguh dengan perempuan yang memeluk agama Islam; jika tidak akan binasalah kedua tanganmu.

Dari hadith di atas dapat dijelaskan bahwasanya menikah itu harus memperhatikan agamanya juga, bahkan dalam hadith tersebut juga mengaskan bahwasanya seorang harus berpegang teguh dengan perempuan yang beragama Islam, jika tidak maka akan binasa.

Profil Muhammadiyah

Salah satu organisasi masyarakat Islam yang terkenal dan terbesar di Indonesia adalah Muhammadiyah. Muhammadiyah terkenal akan pembaharuan pemahaman dan pemikiran Islam yang ada di Indonesia. Namun ada sebagian lapisan masyarakat yang 
menyebut bahwa Muhammadiyah adalah suatu persyarikatan gerakan Islam yakni "Dakwah Islam dan Ammar Makruf Nahi Munkar".39

Muhammad Darwis atau yang lebih dikenal dengan KH. Ahmad Dahlan, lahir di Yogyakarta tahun 1869. Beliau adalah putra dari pasangan suami istri KH. Abu Bakar bin K. Sulaiman, yang sudah masyhur namanya sebagai imam dan khatib di kesultanan Yogyakarta dan Siti Aminah yakni putri dari KH. Ibrahim, penghulu besar di Yogyakarta. Diumur yang ke 20 tahun, KH. Ahmad Dahlan menyelesaikan pendidikannya di Yogyakarta yang mendalami tentang ilmu fiqh, nahwu, tafsir dan sebagainya, beliau memutuskan untuk bearangkat ke tanah suci Makkah untuk menyempurnakan rukun Islam yang ke lima yakni menunaikan ibadah haji sekaligus menuntut ilmu di Makkah. Setelah KH. Ahmad Dahlan kembali ke Indonesia dari Makkah, beliau memutuskan untuk menimba ilmu lagi di Makkah karena dirasa kurang cukup beliau menuntut ilmu sebelumnya.Salah satu guru yang beliau hormati dan banyak menerima ilmu darinya adalah Syaikh Ahmad Khatib.40

Pada tanggal 8 Dzulhijjah 1330 H/18 Nopember 1912 M, KH.Ahmad Dahlan mendirikan organisasi atau persyarikatan Muhammadiyah.Awalnya beliau mendirikan organisasi atau persyarikatan tersebut hanya untuk lingkup wilayah Yogyakarta sebagai sarana beliau untuk mewujudkan tujuannya.Akan tetapi perkembangan Muhammadiyah sangat cepat sehingga tidak hanya di lingkup wilayah Yogyakarta saja, bahkan menjelang tahun 1930 Muhammadiyah sudah tersebar sampai ke wilayah luar pulau Jawa.41

Visi dan Misi dari Muhammadiyah sendiri adalah untuk menegakkan dan memuliakan agama Islam, supaya terciptanya masyarakat Islam yang sebenar-benarnya, maksudnya sebagai

39 Hamdan Hambali, Ideologi dan Strategi Muhammadiyah, (Yogyakarta: PT. Surya Sarana Utama, 2007), Hal. 39.

40 Gandhung Fajar Panjalu, "Implementasi Teori Masalah Dalam Putusan Majelis Tarjih Muhammadiyah", Gandhung Fajar Panjalu, "Implementasi Teori Masalah Dalam Putusan Majelis Tarjih Muhammadiyah", (Skripsi-UIN Sunan Ampel, Surabaya, 2016), 60.

41 Muhammad Kholis, "Studi Komparatif Metode Ijtihad Majelis Tarjih Dan Tajdid Muhammadiyah dan Lembaga Bahtsul Masail Nahdatul Ulama Mengenai Hukum Aborsi", (Skripsi-UIN Sunan Ampel, Surabaya, 2015), 25. 
masyarakat tauhid yang moderat, teladan, toleran, solid dan peduli terhadap sesama.42

Muhammadiyah sebagai organisasi terkenal akan pembaharuan pemahaman dan pemikiran Islam, lebih memperhatikan dalam bidang sosial kemasyarakatan dan aspek kehidupan, karena pada waktu itu umat Islam harus menghadapi masa kolonialisme.43 Yang melatar belakangi berdirinya Muhammadiyah, karena adanya keprihatinan yang serius akan sosial religius dan moral. Keadaan ini disebabkan karena kurangnya pengetahuan, kemiskinan dan keterbelakangan umat Islam pada saat itu.Kegelisahan religius sendiri muncul karena melihat adanya praktik keagamaan yang mekanisme tanpa terlihat kaitanya dengan perilaku sosial dan positif disamping sharat dan tahayul, bid'ah, dan kburafat.Sedangkan kegelisaan moral yang disebabkan oleh kaburnya batas antara baik dan buruk, pantas dan tidak pantas.

Secara umum, Muhammadiyah lebih memperhatikan pada gejala kehidupan yang terjadi di masyarakat yang sangat terpengaruh dengan gaya modern. Fokus perhatian tertuju pada individu setiap masyarakat dengan bertindak kritis, mandiri, apresiatif, dan penuh inisiatif.Akan tetapi Muhammadiyah kurang bersahabat dengan kearifan budaya lokal (terhadap warisan tradisional, kitab kuning misalnya), karena menganggap bahwasanya tidak ada dalam syariat Islam.44

Muhammadiyah terkenal akan pembaharuan pemahaman dan pemikiran Islam. Salah satu ideolog Muhammadiyah, M. Djindar Tamimy mengatakan, bahwa maksud dari pembaharuan tersebut adalah:

1. Pembaharuan dalam arti mengembalikan kepada keasliannya. Tajdid ini sasarannya mengenai prinsip-prinsip perjuangan yang sifatnya tetap.

42 Gandhung Fajar Panjalu, Implementasi..., 61.

43 Hamsah F., Dasar Pemikiran Islam Berkemajuan Mubammadiyah 1912-1923, (Makassar: UIN Alauddin Makassar, 2016), 1.

44 Muhammad Azhar, Posmodernisme Muhammadiyah, (Yogyakarta: Suara Muhammadiyah, 2005), 95. 
2. Pembaharuan dalam arti modernisasi. Tajdid ini sasarannya mengenai masalah seperti metode, strategi perjuangan dan sifatnya sesuai dengan kondisi.

Muhammadiyah berkeinginan menciptakan sebuah rasa bahagia dalam setiap individu ketika mengamalkan ajaran Islam.Melalui pendirian sekolah untuk menambah wawasan setiap umat, membentuk karakter seorang untuk menjadi mubaligh mubalighat, pelayanan kesehatan,45 panti asuhan, rumah yatim dan lain-lain, mereka ingin menciptakan keadaan tersebut.46

Majelis Tarjih dan Tajdid

Secara bahasa majelis berarti sebuah wadah, sedangkan tarjih

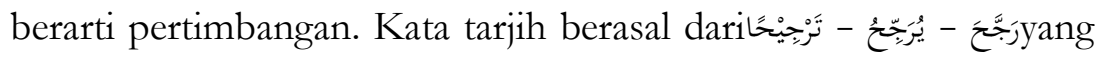
berarti memberi pertimbangan lebih lanjut dari pada yang lain. Dalam ilmu usul al-figh, secara harfiah tarjih diartikan dengan "pengukuhan", maksudnya yaitu mengukuhkan salah satu diantara dua dalil yang bertentangan dan seimbang kekuatannya dengan menyatakan kelebihan dalil yang satu dari lainnya.

Menurut istilah, para ulama berbeda-beda dalam memberikan rumusan tarjih. Seperti sebagian besar ulama Hanafiyah, Syafi'iyyah dan Hanabilah yang memberikan rumusan bahwa tarjih itu adalah perbuatan mujtahid. Hal tersebut dapat dijabarkan bahwa tarjih adalah "Usaha yang dilakukan oleh mujtahid untuk mengemukakan satu diantara dua jalan yang bertentangan, karena adanya kelebihan yang nyata untuk dilakukan tarjih".

Beberapa hal yang melatar belakangi terbentuknya Majelis Tarjih dan Tajdid Muhammadiyah dipengaruhi oleh faktor internal dan eksternal.Faktor internal sendiri terkait dengan perkembangan Muhammadiyah yang sangat cepat, sehingga menyebabkan meningkatnya kualitas dan kuantitas dari anggota Muhammadiyah dan berpengaruh pada pengelolaan oraganisasi atau persyarikatan Muhammadiyah didalamnya.Hal ini terjadi karena Muhammadiyah yang didirikan KH Ahmad Dahlan di Yogyakarta telah berkembang

45 Di awal berdirinya lembaga ini bernama Penolong Kesengsaraan Oemoem (PKO), kemudian berubah menjadi Penolong Kesengsaraan Umum (PKU), kemudian menjadi Pembina Kesejahteraan Ummat (PKU), dan terakhir berubah menjadi Pembina Kesehatan Umum (PKU).

46 Gandhung Fajar Panjalu, Implementasi ...., Hal. 64. 
tidak hanya di Yogyakarta saja tapi hampir di seluruh pulau Jawa dan luar Jawa.

Hal-hal yang perlu diperhatikan antara lain adalah tentang keadaan para anggota organisasi atau persyarikatan tersebut, karena anggota Muhammadiyah berasal dari latar belakang yang berbedabeda dan juga akan berpengaruh pada keragaman aktifitas yang dilakukan oleh anggotanya sesuai dengan situasi dan kondisi di daerah masing-masing mereka berasal.

Faktor eksternal sendiri, diprakarsai dengan adanya fenomena-fenomena yang terjadi dalam kehidupan sosial bermasyarakat yang menyangkut dengan masalah keagamaan.Salah satunya tentang permasalahan tentang khilafiyah, setiap orang berpegang teguh pada pendiriannya masing-masing, sampai-sampai melupakan sifat toleransi terhadap sesama.Perlunya dibentuk sebuah wadah untuk dapat memperkokoh solidaritas dan dapat memayungi anggotanya dari pengaruh buruk dari problematika keagamaan maka berdirilah Majelis Tarjih dan Tajdid tersebut.47

Pembentukan Majelis Tarjih dan Tajdid Muhammadiyah diharapkan dapat menyelesaikan persoalan yang terjadi, agar tidak terjadi perpecahan dan perbedaan pendapat tentang mengamalkan ajaran Islam. Setelahnya, pada kongres ke-17 yang diselenggarakan di Yogyakarta telah disepakati bahwa qaidah tarjih sebagai pedoman dalam melaksanakan aktifitas tarjih sekaligus membentuk kepengurusan Majelis tersebut.48

Salah satu tokoh pemuka Muhammadiyah KH. Sahlan Rasyidi mengungkapkan bahwa Majelis Tarjih dan Tajdid Muhammadiyah sendiri memiliki arti bermusyawarah bersama para pakarnya untuk meneliti, membanding, menimbang, dan memilih dari segala masalah yang diperselisihkan karena perbedaan pendapat dikalangan para umat awam mana yang dianggap lebih kuat, lebih mendasar, dan lebih dekat dari sumber utamanya yakni al-Quran dan hadith.49

$47 \mathrm{Ibid}, 71$.

48 Mulyono Jamal dan Muhammad Abdul Aziz, "Metodologis Istinbath Muhammadiyah dan Nu: Kajian Perbandingan Majelis Tarjih dan Lajnah Batsul Masail", Jurnal Analisis, Volume 7 Nomor 2, (Sya'ban, 1434/ 2013), 188.

49 Ibid.Hlm. 66. 
Majelis Tarjih dan Tajdid Muhammadiyah memiliki tugas yang sangat penting dalam berlangsungnya perkembangan organisasi atau persyarikatan Muhammadiyah.Tugasnya adalah membahas dan memutuskan permasalahan-permaslahan keagamaan yang sedang diperselisihkan.50Akan tetapi dalam perkembangannya majelis tarjih tidak hanya menangani permasalahan-permasalahan yang terjadi dan diperselisihkan, tapi juga mengarah pada penyelesaian persoalan baru yang belum pernah dibahas sebelumnya.51

Metode istimbath Majelis Tarjih dan Tajdid Muhammadiyah

Ijtihad hukum sendiri dalam organisasi atau persyarikatan Muhammadiyah diartikan sebagai wujud mencurahkan segenap kemampuan berfikir dalam menggali dan merumuskan hukum syar'i yang bersifat dzanni dengan menggunakan metode tertentu yang dilakukan oleh para pakarnya.

Dalam hal ini ijtihad bukanlah sebagai sumber hukum, akan tetapi sebagai penetapan sebuah hukum yang berfungsi untuk merumuskan sebuah ketetapan hukum yang belum tertera secara jelas di dalam al-Quran dan al-Sunnah, atau dapat dikatakan sebagai metode penemuan hukum.

Dalam menetapkan sebuah pendapat hukum Muhammadiyah harus memperhatikan 2 hal yang sangat penting demi terciptanya sebuah hukum yang dapat diterima. Adapun dal hal tersebut adalah: 1. Sumber Hukum

Sumber hukum yang digunakan oleh Muhammadiyah adalah al-Qurān dan al-Sunnah al-maqbulat.52

2. Metode Ijtihad

Metode ijtihad yang digunakan oleh Majelis Tarjih Muhammadiyah ada 3 macam antara lain;

a. Bayani(semantik)yaitu metode penetapan hukum yang menggunakan pendekatan kebahasaan.

b. Ta'lili (rasionalistik) yaitu metode penetapan hukum yang menggunakan pendekatan penalaran. Disebut juga ijtibad

50 Fathurrahman Djamil, Metode Ijtihad Majlis Tarjih Mubammadiyah, (Jakarta: Logos Publishing House, 1995), 65.

51 Ibid, 64.

52 Sunnah yang berkualitas shahih dan hasan, serta bisa diterima (makbul) oleh akal sehat dan tidak bertentangan dengan al-Qurān. 
qiyasi, yaitu usaha untuk menentukan suatu masalah yang belum terdapat nash-nya, namun dapat diambil kesimpulan berdasarkan kesamaan 'illat dengan masalah lain yang terdapat nash-nya.

c. Istislabi (filosofis) yaitu metode penetapan hukum yang menggunakan pendekatan kemaslahatan. Hal ini berarti upaya mencari ketentuan hukum sesuatu masalah yang tidak ada nash-nya dengan berdasarkan pada kemaslahatan.

\section{Pendapat Muhammadiyah Tentang Perkawinan Beda Agama}

Perkawinan beda agama menurut pendapat ormas Muhammadiyah yang tertuang dalam Keputusan Majelis Tarjih dan Tajdid PP Muhammadiyah adalah sebuah ikatan perkawinan yang dilakukan oleh seorang muslim atau muslimah denngan non-muslim atau muslimah atau dengan orang musyrik dan ahli kitab.53Adapun yang dibahas dalam penelitian ini hanya yang berkaitan dengan perkawinan antara laki-laki yang beragama Islam dengan wanita ablu al-Kitab.

Muhammadiyah pada dasarnya berpendapat bahwasanya wanita ahlu al-Kitab itu boleh untuk dinikahi oleh seorang laki-laki yang beragama Islam.Hal ini di dasarkan pada dasarnya wanita ablu al-Kitab pada masa Rasululah Saw sudah dalam keadaan syirik, namun al-Qur'an secara eksplisit memperbolehkan untuk menikahi wanita ablu al-Kitab tersebut. Hal ini tertuang pada surat al-Maidah ayat 5 , yaitu sebagai berikut:

Pada hari ini dihalalkan bagimu yang baik-baik.Makanan (sembelihan) orang-orang yang diberi al-Kitab itu halal bagimu, dan makanan kamu halal (pula) bagi mereka. (Dan dibalalkan mangawini) wanita yang menjaga kehormatan diantara wanitawanita yang beriman dan wanita-wanita yang menjaga kehormatan di antara orang-orang yang diberi al-Kitab sebelum kamu, bila kamu telah membayar mas kawin mereka dengan maksud menikabinya, tidak dengan maksud berzina dan tidak (pula) menjadikannya gundik-gundik. Barangsiapa yang kafir sesudah

53 Muhammad Khaeruddin Hamsin, "Perkawinan Beda Agama dalam Tinjauan Syari'ah dan Hukum Positif (Menyoal Pasal 2 ayat (1) UU No. 1 Tahun 1974)", Jurnal Tarjih, Volume 12 No. 2, (1436 H/2014 M), 195. 
beriman (tidak menerima bukum-bukum Islam) maka hapuslah amalannya dan ia di hari kiamat termasuk orang-orang merugi. (QS. al-Ma'idah [5]: 5)

Dari ayat di atas dapat dijelaskan bahwasanya hukum seorang laki-laki yang beragama Islam menikah dengan ablu al-Kitab adalah diperbolehkan.Ayat di atas secara jelas bahwa halal mengawini seorang yang diberi al-Kitab sebelum kamu.Hal tersebut menjadi sebuah dasar hukum yang jelas bahwa boleh menikahi wanita ablu al-Kitab.

Selain hal yang tersebut di atas, Muhammadiyah beranggapan bahwasanya ayat di atas adalah sebuah pengecualian dari keumuman surat al-Baqarah ayat 221 yang pada dasarnya surat tersebut menjelaskan bahwasanya diharamkan seorang laki-laki muslim menikah dengan seorang wanita musyrik. Hal itu disebabkan tidak ada kemungkinan untuk dipertemukan keyakinan antara laki-laki Islam dengan wanita musyrik yang akan sangat berimbas ke kehidupan sehari-harinya. 54

Penjelasan surat al-Baqarah ayat 221 tersebut menurut ormas Muhammadiyah sangat umum sekali. Seorang wanita musyrik itu berbeda sekali dengan wanita ablu al-Kitab. Perbedaan antara wanita ahlu al-Kitab dengan wanita musyrikah ini nampak dalam sebuah ayat al-Qur'an surat al-Bayyinah ayat 1 yang berbunyi:

Orang-orang kafir, yakni abli kitab dan orang-orang musyrik. mengatakan bahwa mereka tidak akan meninggalkan agamanya sebelum datang kepada mereka bukti yang nyata. (QS. al-Bayyinah [98]: 1)

Dari ayat di atas Muhammadiyah beranggapan bahwasanya huruf athaf "waw" mengandung arti adanya sebuah perbedaan antara orang musyrik dengan ablu al-kitab. Huruf tersebut menjadi sebuah penghubung antara kedua kata tersebut sehingga bisa memiliki kedudukan yang berbeda di antara keduanya. 55

Kebolehan perkawinan antara laki-laki muslim dengan wanita ablu al-Kitab oleh Muhammadiyah juga memiliki sebuah alasan, yaitu untuk berda'wah kepada mereka (ablu al-Kitab). Hal ini dilakukan

54Yusuf Qardhawi, Fatwa-Fatwa Mutakhir, (Jakarta: Al-Hamidiy, 1996), 578.

55 Fathurrahman Djamil, Metode Majlis Tarjih Mubammadiyah, (Jakarta: Logos Publishing House, 1995), 144. 
dengan harapan wanita ablu al-Kitabdapat ikut ke agama yang dianut suaminya.56 Sebagai seorang kepala rumah tangga tentunya laki-laki memiliki pengaruh yang sangat besar terhadap apa yang dipimpinnya. Tak terkecuali dengan mengubah kepercayaan yang dianut oleh istrinya yang bisa berubah menjadi kepercayaannya.Hal tersebutlah yang menjadi alasan diperbolehkannya perkawinan ini.

\section{Analisis Komparatif terhadap Hukum Perkawinan Beda Agama menurut Majelis Ulama Indonesia dan \\ Muhammadiyah}

1. Majelis Ulama Indonesia dan Muhammadiyah menggunakan pendekatan nash qath'i dalam metode istinbath hukumnya

Salah satu metode istinbath hukum yang dipakai oleh Majelis Ulama Indonesia dan Muhammadiyah adalah pendekatan nash qath'i. Pendekatan ini langsung menggunakan teks yang ada dalam al-Qur'an maupun hadith dalam menetapkan fatwa suatu permasalahan.

Pendekatan nash qath'i yang digunakan oleh MUI hanya sebatas pada tekstual dari dalil al-Qur'an dan Hadist yang shahih tanpapernah menjelaskan petunjuk (dilalab) makna pada masalah yang dikaji. MUI dalam menggunakan pendekatan ini hanya melihat pada teks ayatsaja tanpa melakukan pengkajian yang mendalam terhadap dalalah (petunjuk)dari ayat itu sendiri.Sedangkan Majelis Tarjih Muhammadiyah memprioritaskan al-Qur'an dan Hadist shabih sebagai sumber primer (utama) dalam berijtihadnya.Hanya saja Majelis Tarjih Muhammadiyah dalam memperlakukan teks al-Qur'an dan alHadist berbeda dengan Komisi Fatwa MUI. Majelis Tarjih Muhammadiyah benar-benar mengkaji teks al-Qur'an dan alHadist dengan memakai pendekatanbayani (semantik) yakni ijtihad terhadap nash mujmal baik karena masih tidak jelas maknanya, ataupun pada lafal tertentu bermakna dua/ganda (musytarak), mutasyabih (multi tafsir) dan sebagainya.

Dalam kaitannya dengan perkawinan beda agama Majelis Ulama Indonesia dan Muhammadiyah sama-sama menggunakan nash al-Qur'an yaitu surat al-Baqarah ayat 221 yang berbunyi:

56Ibid, 146. 
Dan janganlah kamu menikabi wanita-wanita musyrik, sebelum mereka beriman.Sesungguhnya wanita budak yang mukmin lebih baik dari wanita musyrik, walaupun dia menarik hatimu.Dan janganlah kamu menikabkan orang-orang musyrik (dengan wanitawanita mukmin) sebelum mereka beriman.Sesunggubnya budak yang mukmin lebih baik dari orang musyrik, walaupun dia menarike hatimu.Mereka mengajak ke neraka, sedang Allah mengajak ke surga dan ampunan dengan iz̨in-Nya.Dan Allah menerangkan ayat-ayat-Nya (perintah-perintab-Nya) kepada manusia supaya mereka mengambil pelajaran. (QS. al-Baqarah [2]: 221)

Dalam memahami ayat tersebut MUI dan Muhammadiyah berbeda pendapat. MUI melihat hanya sebatas pada teks bahwasanya menikahnya seorang laki-laki muslim dengan nonmuslim hukumnya haram. MUI beranggapan bahwasanya wanitaablu al-Kitab itu termasuk golongan musyrik. Sedangkan Muhammadiyah terkait dengan surat al-Baqarah ayat 221 hanya menuju kepada wanita musyrik saja, bukan wanita ablu al-Kitab.

2. Majelis Ulama Indonesia dan Muhammadiyah memiliki pendapat yang sama bahwa jika perkawinan beda agama banyak menyebabkan kemadharotan maka diharamkan

Majelis Ulama Indonesia dan Muhammadiyah memiliki pendapat yang sama bahwa jika perkawinan beda agamabanyak menyebabkan kemadharotan maka diharamkan. Hal ini dilihat dari akibat yang ditimbulkan oleh perkawinan beda agama tersebut.

Pada dasarnya akibat negatif yang ditimbulkan hanya berpeluang pada dua hal saja. Pertama, beralihya agama suami yang muslim ke agama istrinya. Kedua, pada umumnya agama yang dianut oleh anak itu sama seperti agama yng dianut oleh ibunya. Hal ini dikarenakan bahwasana anak itu lebih dekat pada seorang perempuan. Jika perempuan tersebut beragama selain Islam, maka dikhawatirkan anak akan mengikuti agama ibunya. Hal tersebutlah yang dianggap menjadi kemadharatan yang asasi, Karena seorang laki-laki tidak bisa menjaga agamanya dan anakanaknya. Padahal pada dasarnya menjaga agama adalah termasuk salah satu maqashid syariah yang lima. 
Hal tersebut juga sesuai dengan kaidah fiqh yang berbunyi sebagai berikut:57

Menolak kemafsadahan lebih didahulukan daripada meraih kemaslahatan.

Dari kaidah di atas dapat disimpulkan bahwasanya bahwasanya lebih didahulukan meninggalkan sebuah kemafsadatan daripada meraih sebuah kemaslahatan.Adapun kemafsadatan dan kemaslahatan dapat diketahui dengan akal sehat dengan pengalaman dan kebiaaan manusia.Sedangkan kemafsadatan dan kemsalahatan dunia dan akhirat tidak bisa diketahui dengan kecuali dengan dalil syara'.

3. Pertimbangan yang digunakan

Majelis Ulama Indonesia menghukumi perkawinan beda agama haram dengan mempertimbangakanbahwa belakangan ini disinyalir banyak terjadi perkawinan beda agama yang banyak mengundang perdebatan di antara sesama umat Islam, akan tetapi juga sering mengundang keresahan di tengah-tengah masyarakat. Selain hal tersebut di tengah-tengah masyarakat juga telah muncul sebuah pemikiran yang membenarkan perkawinan beda agama dengan dalih hak asasi manusia dan kemaslahatan.

Guna ntuk mewujudkan dan memelihara ketentraman dan kerukunan dalam kehidupan berumah tangga, MUI memandang perlu menetapkan fatwa tentang perkawinan beda agama untuk dijadikan pedoman.

Sedangkan Muhammadiyah menghukumi perkawinan beda agama boleh dengan memperhatikan dan mempertimbangkan dari sejarah Islam, bahwasanya Nabi Muhammad Saw pernah menikah dengan seorang wanita Nasrani yang berasala dari Mesir, yaitu Maria al-Qibthiyyah. Begitu pula beberapa sahabat Nabi yang juga menikah dengan wanita ablu al-Kitab.Dari melihat sejarah tersebut Muhammadiyah beranggapan bahwasanya perkawinan beda agama itu diperbolehkan.

57 A. Djazuli, Kaidah-Kaidah Fikih, (Jakarta: Prenadamedia Group, 2016), 29. 
4. Perbedaan pemahaman dalil yang digunakan

Dalil yang digunakan MUI dalam menghukumi perkawinan beda agama adalah surat al-Baqarah ayat 221. Yaitu sebagai berikut:

Dan janganlah kamu menikabi wanita-wanita musyrik, sebelum mereka beriman.Sesunggubnya wanita budak yang mukmin lebih baik dari wanita musyrik, walaupun dia menarik, batimu.Dan janganlah kamu menikabkan orang-orang musyrik (dengan wanitawanita mukmin) sebelum mereka beriman. Sesunggubnya budak yang mukmin lebib baik dari orang musyrik, walaupun dia menarik. batimu.Mereka mengajak ke neraka, sedang Allah mengajak ke surga dan ampunan dengan izin-Nya.Dan Allah menerangkan ayat-ayat-Nya (perintah-perintab-Nya) kepada manusia supaya mereka mengambil pelajaran. (QS. al-Baqarah [2]: 221)

Dalam memahami ayat di atas, MUI melihat hanya sebatas pada teks bahwasanya perkawinan antara seorang laki-laki muslim dengan non-muslim hukumnya haram. MUI beranggapan bahwasanya wanitaahlu al-Kitab itu termasuk golongan musyrik.

Muhammadiyah beranggapan bahwasanya ayat di atas tidak bisa dijadikan hukum perkawinan antara laki-laki muslim dengan wanita ablu al-Kitab dikarenakan ayat di atas terlalu umum dan turun sebelum surat al-Maidah ayat 5 yang menerangkan bahwaanya hukum perkawinan antara laki-laki muslim dengan wanita ablu al-Kitab itu diperbolehkan. Karenanya, tidak mungkin ayat yang lebih awal turun me-naskh ayat yang lebih akhir turunnya.

Muhammadiyah pada dasarnya berpendapat bahwasanya wanita ablu al-Kitab itu boleh untuk dinikahi oleh seorang laki-laki yang beragama Islam.Hal ini dikarenakan pada dasarnya wanita ablu al-Kitab pada masa Rasululah Saw sudah dalam keadaan syirik, namun al-Qur'an secara jelas memperbolehkan untuk menikahi wanita ahlu al-Kitab tersebut. Hal ini tertuang pada surat al-Maidah ayat 5 , yaitu sebagai berikut:

Pada hari ini dihalalkan bagimu yang baik-baik.Makanan (sembelihan) orang-orang yang diberi al-Kitab itu balal bagimu, dan makanan kamu halal (pula) bagi mereka. (Dan dihalalkan 
mangawini) wanita yang menjaga kehormatan diantara wanitawanita yang beriman dan wanita-wanita yang menjaga kehormatan di antara orang-orang yang diberi al-Kitab sebelum kamu, bila kamu telah membayar mas kawin mereka dengan maksud menikahinya, tidak dengan maksud berzina dan tidak (pula) menjadikannya gundik-gundik. Barangsiapa yang kafir sesudah beriman (tidak menerima hukum-bukum Islam) maka hapuslab amalannya dan ia di hari kiamat termasuk orangorang merugi. (QS. al-Ma'idah [5]: 5)

5. Perbedaan pandangan pemahaman ahlu al-Kitab

Menurut pendapat Majelis Ulama Indonesia menikahi wanita ablu al-Kitab itu haram hukumnya, dengan memperhatikan kenyataan bahwa pada kenyataannya wanita Nashrani dan Yahudi itu termasuk kategori musyrik. Hal tersebut mengacu pada firman Allah Swt sebagai berikut:58

Sesungguhnya telah kafirlah orang-orang yang berkata: "Sesungguhnya Allah ialah Al Masih putera Maryam", padahal Al Masih (sendiri) berkata: "Hai Bani Israil, sembahlah Allah Tuhanku dan Tuhanmu". Sesungguhnya orang yang mempersekutukan (sesuatu dengan) Allah, maka pasti Allah mengharamkan kepadanya surga, dan tempatnya ialah neraka, tidaklah ada bagi orang-orang zalim itu seorang penolongpun.(al-Maidah[5]: 72)

Menurut pandangan Majelis Ulama Indonesia surat alBaqarah ayat 221 harus diberlakukan dengan penuh termasuk juga kepada wanita ahlu al-Kitab dengan mempertimbangkan ayat di atas.

Muhammadiyah beranggapan bahwasanya wanita ablu alKitab itu tidak termasuk musyrikat sebagaimana yang tercantum dalam surat al-Baqarah ayat 221. Hal tersebut disebabkan menurut Muhammadiyah banyak ayat yang menbedakan antara ahlu al-Kitab dengan musyrik dengan mempertimbangkan analisis kebahasaan. Di antaranya adalah sebagai berikut:

Orang-orang kafir dari Ahli Kitab dan orang-orang musyrik tiada menginginkan diturunkannya sesuatu kebaikan

58 Fathurrahman Djamil, Metode Ijtihad Majlis Tarjih Muhammadiyah, (Jakarta: Logos Publishing House, 1995), 147. 
kepadamu dari Tuhanmu.Dan Allah menentukan siapa yang dikehendaki-Nya (untuk diberi) rahmat-Nya (kenabian); dan Allah mempunyai karunia yang besar. (al-Baqarah [12: 105)

Orang-orang kafir, yakni abli kitab dan orang-orang musyrike. mengatakan babwa mereka tidak akan meninggalkan agamanya sebelum datang kepada mereka bukti yang nyata. (QS. al-Bayyinah [98]: 1)

Dari kedua ayat di atas Muhammadiyah beranggapan bahwasanya huruf athaf "waw" mengandung arti adanya sebuah perbedaan antara orang musyrik dengan ahlu al-kitab.Huruf tersebut menjadi sebuah penghubung antara kedua kata tersebut sehingga bisa memiliki kedudukan yang berbeda di antara keduanya.

\section{Penutup}

Berdasarkan hasil analisis penulis tentang hukum perkawinan beda agama menurut Majelis Ulama Indonesia dan Muhammadiyah, dapat diambil kesimpulan bahwa Majelis Ulama Indonesia berpendapat bahwa hukum perkawinan beda agama antara laki-laki muslim dengan wanita ablu al-Kitab adalah haram. Yang mendjadi dasar MUI mengharamkan hal tersebut adalah surat al-Baqarah ayat 221 serta al-Mumtahanah ayat 10. Alasan MUI mengharamkan adalah bahwasanya wanita ahlu al-Kitab itu sama seperti wanita musyrik. Yaitu sama-sama menyekutukan Allah Swt.

Muhammadiyah berpendapat bahwasanya perkawinan beda agama antara laki-laki muslim dengan wanita ahlu al-Kitab hukumnya diperbolehkan. Adapun yang menjadi dasar diperboehkannya hukum tersebut dengan meperhatikan surat alMaidah ayat 5. Muhammadiyah beranggapan bahwasanya wanita ahlu al-Kitab itu beda dengan wanita musyrik. Hal tersebut sesuai dengan ketentuan surat al-Baqarah ayat 105 dan al-Bayyinah ayat 1.

Majelis Ulama Indonesia dan Muhammadiyah sama-sama menggunakan pendekatan nash qath'i dalam metode istinbath hukumnya. selain persamaan tersebut, MUI dan Muhammadiyah juga memiliki pendapat yang sama tentang perkawinan beda agama. Apabila perkawinan tersebut banyak menyebabkan kemadharotan maka hukumnya haram. MUI dan Muhammadiyah berbeda pandangan dalam menghukumi perkawinan beda agama. Untuk 
perbedaan sudut pandang, MUI menggunakan pertimbangan terjadi perkawinan beda agama dalam kehidupan masyarakat yang menimbulkan konflik antar sesama umat Islam sehingga mengakibatkan keresahan, maka perkawinan beda agama dihukumi haram. Muhammadiyah beranggapanperkawinan beda agama boleh dengan memperhatikan dan mempertimbangkan dari sejarah Islam, bahwasanya Nabi Muhammad Saw pernah menikah dengan seorang wanita Nasrani yang berasal dari Mesir, yaitu Maria al-Qibthiyyah. Begitu pula beberapa sahabat Nabi yang juga menikah dengan wanita ablu al-Kitab.Selain pertimbangan tersebut MUI juga memiliki pendapat bahwa menikahi wanita ablu al-Kitab itu haram hukumnya, dengan memperhatikan kenyataan bahwa pada kenyataannya wanita Nashrani dan Yahudi itu termasuk kategori musyrik. Sedangkan menurut Muhammadiyah beranggapan bahwasanya wanita ablu alKitab itu tidak termasuk musyrikat sebagaimana yang tercantum dalam surat al-Baqarah ayat 221. Hal tersebut disebabkan menurut Muhammadiyah banyak ayat yang menbedakan antara ablu al-Kitab dengan musyrik dengan mempertimbangkan analisis kebahasaan dalam surat al-Baqarah ayat 105 dan al-Bayyinah ayat 1 .

\section{Daftar Pustaka}

Wahbah az-Zuhaili. Figh Islam Wa Adillatubu. Jakarta: Gema Insani. 2011.

Muhammad Azhar. Posmodernisme Muhammadiyah. Yogyakarta: Suara Muhammadiyah. 2005.

Desri Ari Enghariano dan Amaruddin Asra."Pernikahan Beda Agama Menurut Rasyid Ridha dan Al-Maraghi.Jurnal Syahadah. Vol. V, No. 1. April, 2017.

Fathurrahman Djamil. Metode Ijtibad Majlis Tarjïh Mubammadiyah. Jakarta: Logos Publishing House. 1995.

A Djazuli. Kaidah-Kaidah Fikih. Jakarta: Prenadamedia Group.2016. Neng Djubaidah. Pencatatan Perkawinan dan Perkawinan Tidak dicatat. Jakarta: Sinar Grafika. 2010.

Ernawati."Studi Komparatif Metode Istinbat Nahdlatul Ulama dan Majelis Ulama Indonesia tentang Hukum BPJS Kesehatan".Skripsi-UIN Walisongo, Semarang. 2018.

F. Hamsah Dasar Pemikiran Islam Berkemajuan Muhammadiyah $1912-$ 1923. Makassar: UIN Alauddin Makassar. 2016. 
Abdul Rahman Ghozali. Fiqh Munakahat, Jakarta: Kencana, 2010.

Hambali, Hamdan. Ideologi dan Strategi Muhammadiyah. Yogyakarta: PT. Surya Sarana Utama. 2007.

Muhammad Khaeruddin Hamsin. "Perkawinan Beda Agama dalam Tinjauan Syari'ah dan Hukum Positif (Menyoal Pasal 2 ayat (1) UU No. 1 Tahun 1974)".Jurnal Tarjïh, Volume 12 No. 2, $1436 \mathrm{H} / 2014 \mathrm{M}$.

Sofia Hardani. "Analisis tentang Batas Umur Untuk Melangsungkan Perkawinan menurut Perundang-Undangan di Indonesia". An-Nida': Jurnal Pemikiran Islam, Vol. 40, No. 2. Juli-Agustus. 2015.

Heri Fadli Wahyudi dan Fajar."Metode Ijtihad Komisi Fatwa Majelis Ulama Indonesia dan Aplikasinya dalam Fatwa”.Cakrawala: Jurnal Studi Islam, Vol. 13, No. 2. 2018.

Dedi Irawan. "Pernikahan Beda Agama dalam Al-Qur'an (Analisis Penafsiran Al-Maraghi atas QS. Al-Baqarah: 221 dan QS. Al-Maidah: 5)". Skripsi--Universitas Islam Negeri Syarif Hidayatullah, Jakarta. 2011.

Iffatul Umniati Ismail. "Telaah Kritis Metodologi Istinbath MUI (Studi Kasus Fatwa tentang Golput)". Jurnal Media Syariah, Vol. XIII No. 1, Januari - Juni, 2011,.74.

Kamto."Perkawinan Masyarakat Samin dalam Perpektif Sosiologis dan Teologis".Jurnal Studi Hukum Islam. Vol. 3, No. 2. JuliDesember. 2016.

Helmi Karim. KonsepIjtibad Majelis Ulama Indonesia dalam Pengembangan Hukum Islam.Pekanbaru: Susqan Press, 1994.

Ma'ruf Amin dkk. Himpunan Fatwa Majelis Ulama Indonesia. Jakarta: Erlangga, 2011.

Muhammad Kholis. "Studi Komparatif Metode Ijtihad Majelis Tarjih Dan Tajdid Muhammadiyah dan Lembaga Bahtsul Masail Nahdatul Ulama Mengenai Hukum Aborsi'.Skripsi-UIN Sunan Ampel, Surabaya. 2015.

Abdul Majid Khon. Fiqh Munakahat. Jakarta: Amzah. 2011.

Noeng Muhadjir. Metode Penelitian. Jakarta: Rake Sarasin. 1989.

Muhammad Taufiq dan Anis Tyas Kuncoro. "Pasuwitan Sebagai

Legalitas Perkawinan: Telaah Hukum Islam terhadap 
Perkawinan Suku Samin di Kabupaten Pati”.Jurnal Ulul Albab. Vol. 1, No. 2. April. 2018.

Mulyono Jamal dan Muhammad Abdul Aziz, "Metodologis Istinbath Muhammadiyah dan NU: Kajian Perbandingan

Majelis Tarjih dan Lajnah Batsul Masail”. Jurnal Analisis,

Volume 7 Nomor 2, .Sya'ban, 1434/ 2013.

Nasrullah. "Majelis Ulama Indonesia (MUI); Studi atas Penggunaan

Metodologi Qiyas sebagai Upaya Penetapan Hukum Islam di Indonesia". Al-Fikra: Jumal Ilmiah Keislaman. Vol. 16, No. 2, Juli - Desember, 2017.

Ratna Jati Ningsih. "Perkawinan Beda Agama (Studi Analisis Pemikiran Quraish Shihab dalam Tafsir Al-Misbah)". Skripsi--IAIN Surakarta. 2012.

Indra Nurfiati. "Kedudukan Majelis Ulama Indonesia (MUI) dalam Ketatanegaraan Indonesia Ditinjau dari Perspektif Fiqh Siyasah".Skripsi-UIN Sunan Ampel, Surabaya, 2016.

Gandhung Fajar Panjalu. "Implementasi Teori Masalah Dalam Putusan Majelis Tarjih Muhammadiyah", Gandhung Fajar Panjalu, "Implementasi Teori Masalah Dalam Putusan Majelis Tarjih Muhammadiyah", Skripsi-UIN Sunan Ampel, Surabaya. 2016.

A. Suriyaman Mustari Pide. Hukum Adat Dabulu, Kini, dan Akan Datang, Jakarta: Kencana. 2017.

Yedi Purwanto. "Kawin Beda Agama dan Perlindungan Ham : Studi Kritis atas Undang-Undang Pernikahan Nomor 1 Tahun 1974 dan Undang-Undang Dasar 1945”.Jumal, Asy-Syari'ah. Vol. 16, No. 3. Desember. 2014.

Yusuf Qardhawi. Fatwa-Fatwa Mutakhir, Jakarta: Al-Hamidiy. 1996.

Dede Rihana. "Pernikahan Beda Agama Prespektif Al-Qur'an (Kajian Sosio-Historis Terhadap QS. Al-Mumtahanah/60: 10)". Skripsi--UIN Syarif Hidayatullah, Jakarta. 2017.

Idris Ramulyo. Hukum Perkawinan Islam. Jakarta: Bumi Aksara. 1992. Ruslan."Studi atas Penafsiran Al-Qurtuby terhadap Ayat-Ayat tentang Nikah Beda Agama dalam Kitab Al-Jami’ Li Ahkam Al-Qur'an".Skripsi--Universitas Islam Negeri Sunan Kalijaga, Yogyakata. 2009. 
Soemiyati. Hukum Perkawinan Islam dan Undang-Undang Perkawinan, Yogyakarta: Liberty. 2007.

Subekti. Kitab Undang-Undang Hukum Perdata, UUPA dan UU Perkawinan, Jakarta: Pradniya Paramita. 2004.

Sugiyono. Metode Penelitian Kuantitatif, Kualitatif, dan R\&D. Bandung: Alfabeta. 2016.

M. Joko Subiyanto. "Fikih Pernikahan Lintas Agama (Studi

Terhadap Pemikiran Hukum Wahbah Az-Zuhailī Tentang Perempuan Ahl Al-Kitab)".Skripsi--Universitas Islam Negeri Sunan Kalijaga.Yogyakata.2012.

Amir Syarifuddin. Hukum Perkawinan di Indonesia: Antara Fiqib Munakahat dan Undang-Undang Perkawinan. Jakarta: Kencana. 2009.

M. A. Tihani,. Fikih Munakahat. Jakarta: Rajawai Pers. 2010.

Undang-Undang Dasar Negara Republik Indonesia 1945 Pasal 29 Ayat (2).

Undang-Undang No. 1 Tahun 1974 tentang Perkawinan.

Wasman dan Wadah Nuroniyah.Hukum Perkawinan Islam di Indonesia. Yogyakarta: Teras. 2011. 